\title{
THE POLITICS OF NAMES: RETHINKING THE SIGNIFICANCE OF NAMING A DISCIPLINE FROM BIBLICAL ARCHAEOLOGY TO THE ARCHAEOLOGY OF THE NEAR EAST
}

\author{
Gabriela Rodrigues ${ }^{1}$
}

\begin{abstract}
This paper examines the trends in terminology for the archaeological practice in Israel and Palestine through time. The adoption of terms from 'Biblical Archaeology' to the archaeology of a specific age in a determined geographical area appears to reflect not only the research scope but also its political agenda. After an overview of the most common terminology in the literature, the paper addresses how these names can affect the practice of archaeology in the region of the Near East, in an appeal for its practitioners to the theoretical aspects of the discipline.
\end{abstract}

Keywords

'Biblical Archaeology'; 'Archaeology of Palestine'; Near Eastern Archaeology; Terminology; History of Science; Politics of Archaeology.

1 PhD, Ruprecht-Karls-Universität Heidelberg, Heildelberg, Germany. E-mail: gab.rodrigues@gmail.com 


\section{Resumo}

Este artigo examina as tendências em terminologia para a prática arqueológica em Israel e na Palestina ao longo do tempo. A adoção de termos como "Arqueologia Bíblica" até a arqueologia de um período determinado numa região geográfica específica reflete não apenas o escopo da pesquisa, mas principalmente sua agenda política. Após uma apresentação dos termos mais comumente empregados na literatura, este texto discute como o nome da disciplina pode afetar a prática arqueológica no Oriente Próximo, ao mesmo tempo em que faz um apelo aos praticantes da disciplina que considerem a importância da discussão teórica.

\section{Palavras-chave}

"Arqueologia Bíblica"; "Arqueologia da Palestina"; Arqueologia do Oriente Próximo; Terminologia; História da Ciência; Arqueologia e Política. 


\section{Introduction}

During its history, the archaeology practiced in the region known by some as the Holy Land has received many names and definitions. This broad classification is, as a matter of fact, a result of the history of a discipline, so controversial as its geographical scope. In the region of Israel and Palestine - as well as in the broader Near East - politics and religion have always been particularly intertwined. Scientific research in the area carried out in the $1^{\text {th }}$ and $20^{\text {th }}$ centuries mainly by Europeans is another important element, making it virtually impossible to separate science, faith and politics in the area. Within this context, the archaeological investigations in the region have constantly fluctuated between the realm of religious studies and the archaeological discipline. All these led to challenges in defining the discipline, its scope and aims, and therefore its terminology.

The more compelling name 'Biblical archaeology' addresses an explicit connection between archaeology and the Bible. This term has been broadly adopted, although in different ways. There is, for example, biblical archaeology as the archaeology carried out in sites mentioned in the biblical texts, which would be for example the archaeology of Jerusalem, Jericho, or Megiddo. On the other hand, there is the archaeology of the Near East excavating the periods in which the biblical texts emerged - or which they refer to. Moreover, there is the archaeology motivated by a specific biblical subject or issue, such as the conquest of Canaan or the United Monarchy.

Alternatively, the terms 'archaeology of the Holy Land' (Negev, 2001; Magness, 2012) or in the Holy Land (Kenyon, 1960; Balter, 2000) have also been used.

'Archaeology of Palestine' is also a traditional choice among scholars engaged in the area. The 'archaeology of ancient Israel', on the other hand, is seen as a small part of Palestinian archaeology (Franken, FrankenBattershill, 1963).

Finally, there is the term Near Eastern archaeology. 'Near East', together with the terms 'Middle East' and 'Far East', was also created by Westerners during the $19^{\text {th }}$ and $20^{\text {th }}$ centuries, in an attempt to specify regions inside the broader term, Orient. Near East is usually adopted to describe the 
modern portion of land from the Mediterranean Sea to Iraq, from Egypt to Turkey. The traditional term to refer to the same area in ancient times is Ancient Near East.

There is no general consensual approach to what term should be used. Nevertheless, the study of the terms applied throughout time helps draw a portrait of a discipline, forged in a context of disputes and conflicts. The aim of the current review is firstly to assess the different terms and their uses, and secondly to address the implications of these uses to the interpretation and practice of the discipline. Finally, it intends to make current practioners of the discipline aware of the power and limitations of their work, as an archaeological practice.

\section{Biblical Archaeology}

For the American theologian who has been called "the father of biblical archaeology", the term should comprise the archaeology of "all Biblical lands, from India to Spain and from southern Russia to South Arabia, and to the whole history of those lands from about 10,000 B.C. or even earlier, to the present time" (Albright, 1966: 13). As Cross (1973: 3) describes, Albright's biblical archaeology should include "papyri from Egypt, the onomasticon of the Amorites, a cylinder seal from Greece, Phoenician ivories from Spain, an ostracon from Edom, a painted Athenian pot, a skull from Carmel".

William F. Albright (1891-1971) was a biblical scholar active in Palestine from the 1920s until the 1960s. He is the first to define such a broader view of biblical archaeology. This generalist approach emphasizes the main characteristic of biblical archaeological research, from the first efforts to Albright's time: the starting point of the investigation was the Bible.

Since the first scientific efforts in Palestine, biblical archaeology was very often interpreted as the study of the antiquity of the Bible, which had the Bible itself as the main source of research. According to this perspective, the Bible could offer reliable information on ancient life in its sacred, political and domestic aspects, which could be easily combined with archaeological excavations, whose results were going to illustrate such aspects of the past (Davis, 2004: 20). 
The central role the biblical text played can also be suggested by the scholars engaged in those researches througout its first decades. Early explorations before World War I as well as during the British Mandate were commonly conducted and sponsored by biblical scholars. From Robinson to Albright, they included also Europeans such as E. Sellin and R. de Vaux.

Nevertheless, as Dever (2003: 57) remarks, Albright also applied the term Palestinian archaeology quite often. Indeed, the scholar known to have spread the use of biblical archaeology is George E. Wright, a famous pupil of Albright. He defines biblical archaeology as a "special 'armchair' variety of general archaeology", which, although "intelligently concerned with stratigraphy and typology upon which the method of modern archaeology rests", has "the understanding and exposition of the Scriptures" as the central goal (Wright, 1947a: 7, 1947b: 74). Wright called the the magazine he created for the American Schools of Oriental Research (ASOR) The Biblical Archaeologist. It was published from 1938 to 1998 under that name. After that, ASOR changed its title to Near Eastern Archaeology.

The use of 'Biblical archaeology' was not an American exclusivity. In fact, it can be found in publications in many different languages until these days. In French, for example, there was the famous Cahiers d'Archéologie Biblique under Andre Parrot. Among German-speaking scholars, Biblische Archäologie has been applied in monographs, lectures, and dictionaries since the end of the 18th century. Between 1787 and 1799 Johann Joachim Bellermann (1754-1842), who was a professor in Berlin, published his Handbuch der biblischen Literatur. Its first volume was dedicated to Biblische Archäologie. Ten years later, Johann Jahn (1750-1816) published the first book of a series entitled Biblische Archäologie. The volumes were dedicated to Häusliche Alterthümer (1817), to Politische Alterthümer (1825), and to Heilige Alterthümer (1805). Moreover, from 1810 to 1842, Wilhelm Gesenius (1786-1842) worked at the University of Halle, where he lectured on Biblische Archäologie, Biblische Alterthümer, and Hebräische Archäologie (Hübner 2013). More recently, the most famous German textbook on the topic is called Einführung in die Biblische Archäologie by Volkmar Fritz.

A popular term still today, 'Biblical archaeology' continues to appears not only on books and magazine covers (Cline, 2009; see also the Biblical Archaeology Review), but it is found more than 3,5 million times on Google. The term still appears in encyclopedias of archaeology such as Encyclopedia 
of historical archaeology (Orser, 2002) and Encyclopedia of Archaeology (Pearsall, 2008). In fact, in the last case, with a much broader meaning that includes an additional geographical and chronological framework, such as the reserach on the "fertile crescent" from the Neolithic Age through late antiquity (Sharon, 2008: 920).

\section{Archaeology of Palestine}

During the 19th century, however, most of the publications such as travel journals or exploration reports adopted the term Palestine to describe the region, instead of any other biblical related name. Among them were the German Ulrich Jasper Seetzen (1767-1811) and the British James Silk Buckingham (1786-1855)2. Even the biblical scholar Edward Robinson used Palestine in the title of his well-known book, Biblical Researches in Palestine, Mount Sinai and Arabia Petrae (1841). Palestine was also the description adopted by Frederic Bliss and Stewart Macalister to their report: Excavations in Palestine during the years 1898-1900 (1902).

It is safe to say that there was no deliberate intentions in adopting such terminology, besides folowing the status quo. Their use of Palestine was based on a tradition dating back to ancient Greek writers, such as Herodotus, who used to identify the area between the Mediterranean Sea and the Jordan River as Palestine (Rainey, 2001).

At the time Albright arrived in the region, Palestine had, though, another meaning. This was a different one, created after the First World War, when the Palestine Question, the Balfour Declaration and the idea of the establishment of a Jewish national home in Palestine made it necessary to (re-)define Palestine and its territorial borders (Susser, 2012).

Nevertheless, the term is still in use. On the one hand, bz scholars involved in excavations in Israel, but particularly in Jordan, in search of a broader definition to their field (Rast, 1992: 16). Besides, Palestinian archaeology is currently used to detemine researches on territories of the Palestinian Authoritz, under the direction of the Department of Antiquities and Cultural Heritage and the Al-Quds University (Bohannon, 2006).

2 Seetzen (1854) Reisen durch Syrien, Palästina, Phönicien, die Transjordan-Länder, Arabia Petraea und Unter-Aegypten; Buckingham (1821) Travels in Palestine Through the Countries of Bashan and Gilead, East of the River Jordan. 


\section{Alternative Terminologies}

Known for leading the epistemological discussions on biblical archaeology, Dever proposed, in the beginnings of the 1970s, the adoption of a new name: 'Syro-Palestinian archaeology'. At least in the theoretical plane, the scholar became disturbed by the umbilical connection between Bible and archaeology in Palestine (Dever, 1982: 103). Inspired by the development of the so-called New Archaeology in the United States, Dever defended a necessary change in biblical archaeology, in order to approach anthropological and processual thoughts, and leave the theological orientation behind. In this context, the author speaks of death, decline or fall of biblical archaeology.

Therefore, according to his later definition, Syro-Palestinian archaeology became an "autonomous archaeological discipline, no longer an ancilary branch of biblical or theological studies" as its geographiocal scope turned from Bible Lands to "ancient southern-central Syria and Palestine, both west and east of the Jordan (i.e., modern Israel, Jordan, Lebanon, and parts of Syria), or more properly ancient 'Greater Canaan'". Besides, its chronological scope expanded "far beyond the 'biblical period', embracing everything from the Lower Paleolithic to the Ottoman period". He also classifies its aims and methods as those "of other branches of archaeology (and anthropology)". Indeed, he explicitly describes the agenda as "not drawn from the Bible, much less from theological questions" (Dever, 2001: 60-61).

The American scholar argued that his efforts to revive and popularize Syro-Palestinian Archaeology - which was also a term already used by Albright - were broadly accepted, especially during the 1980s and 1990s, even by Israeli scholars (Dever, 2001: 62; see also Mazar 1990).

According to Burke (2006: 83), however, 'archaeology of the Levant' has been adopted more frequently, especially by European scholars. He advocates for its use based not only on geographical features, but also on the observation of the material culture of the region, making it the first internal terminology for the archaeological practice in the region. This assumes, though, that Levant is a "contiguous cultural zone" (Burke, 2006: 100). 
Other than that, archaeologists also use the terms archaeology of Israel/Jordan or prefer to adopt the historical period of the research as its name, such as the archaeology of the Iron Age.

\section{Why does it matter?}

In theoretical terms, the way scholars refer to their field of studies, as well as the way they describe it and report their activities reveals much about these scholars and the character of their research, their starting points and aims.

Archaoelogy as we know it today is a modern enterprise. That is not only to say that that Modernity gave archaeology the conditions to exist (Thomas, 2004), but also that modern concepts and operations, such as illumination, industrialization, capitalism, imperialism, colonialism, or distinctions as 'ancient vs. modern', 'civilization vs. barbarism', are ontologically constitutive of archaeology (González-Ruibal, 2013).

The development of an archaeological consciousness, that is a consensus regarding its identity, models and theory (Hodder, 2003), led the discipline towards its independence, to the awareness of its epistemology (Renfrew; Bahn, 2005) and provoked the break into the boundaries of disciplinary innocence (Clarke, 1973: 6).

As a consequence, archaeologists began reflecting on the history of their own discipline. This search for the origins and evolution of archaeology - or its genealogy - has been revealing archaeology's darkest sides (Silberman, 1989; Kohl, Fawcett, 1995; Marchand, 1996; Meskell, 1998; Hingley, 2000; Díaz-Andreu, 2007; Ben-Yehuda, et al. 2007; Funari, Ferreira, 2008; Hamilakis, 2009). The study of the history and theoretical developments of the archaeological practice has become an important tool in favor of a more egalitarian and libertarian discipline, which can promote more complex understandings of the past (Gnecco, 2009; Haber, 2012).

Nevertheless, the archaeological practice in the Near East has been repeatedly reported as a list of the deed of the pioneers, the founding fathers of the field, and their great discoveries, thus, tracing a noble origin - i.e. European enlightened - to the archaeological practice in the region. As Meskell (1998: 2) once noted, "Mediterranean, Near Eastern and 
Egyptian [archaeologies] are marginalized fields whose practitioners are considered still trapped in the throes of culture history and thus reticent to engage in contemporary issues of politics or praxis".

Whether this critic still stands, 20 years later, is not the point of this discussion. The opportunity to tell the history of a discipline is an opportunity to reinforce one's own claims as a part of its practice (Haber; Roberts, 2004). This is very much true for the name one choose to identify their work. Terminology might not be a big issue for the archaeologists engaged in the Near East now, but it is an important tool of reflection. It identifies research agendas, affiliations, objectives, that is the very identity of the discipline throughout time.

In Albright's definition of biblical archaeology, he had a clearly political and theoretical position, namely to prove the biblical critics wrong through the study of the evolution of the history of religions - "from the Stone Age to Christianity" to its later developments in the Graeco-Roman world (Albright 1933, 1940, 2006 [1946], 1966). According to him, in order to investigate this evolution, archaeology and historical studies (comprising language and literature) had to be combined. He departed from the biblical text as the main source for his scientific investigation and saw the archaeological material from the Holy Land through it in order to elucidate the interpretation of specific biblical passages. Under Albright, biblical archaeology became the "process of constructing biblical theory on the realia of archaeology" (Davis, 2004: 85).

Thus, for what became known as Albright's school, archaeology should be used as a tool to prove the Bible right. Archaeology was important since it could offer the evidence for an interpretation that was already there. Therefore, biblical archaeology was rather an ancillary discipline of Theology, than an independet field of studies.

The period of the Old Testament was then the focus of biblical archaeology. This is due to the fact that most theological controversies of the time were related to it, from the Babel-Bibel Streit in the beginnings of the $20^{\text {th }}$ century to Albright/Wright's efforts to contradict what the first classified himself as German nihilism from Albrecht Alt, Martin Noth and Gerhard von Rad (Soggin, 1960; Wright, 1960; Rad, 1961).

At one point, the adoption of 'Biblical archaeology' earned a patriotic character, especially after Dever called it an American phenomenon. He 
claims that there was biblical archaeology when Americans decided to search for "external 'proofs', provided by archaeological discoveries" (Dever, 1997: 315), until the moment when New Archaeology revolutionized American archaeology, so that biblical archaeology became an unacceptable term. This can only be understood as an insistent claim for exclusivity or leadership of the Americans in the field of biblical archaeology, to the point of ignoring the developments of the discipline before World War I.

In German language, Biblische Archäologie was understood as the study of things - here the meaning of things is closer to concepts and ideas mentioned in the Bible, and could be used interchangeably with Biblische Altertümer, Biblisch Altertumskunde, or even as a synonym for Hebräische Archäologie ${ }^{3}$. At the time of these publications, archaeology was used as a general synonim for antiquities (Altertümer).

In this sense, those authors combined topics related from administration, governability and wars, to details of daily life, such as crafts and trading, or birth, marriage, and death, as well as diet, cult, and religious practices. Most of the publications started with a general introduction to the geography, climate, fauna, and flora of the Biblical lands, which was followed by a history of Israel from Abraham to the Romans (Hübner, 2013: 461). They usually contained a presentation of Israel's neighbors, because, as Jahn (1817: 3) pointed out, for it to be Biblische Archäologie, the Biblical scholar needed to know the Egyptians, the Hittites, the Assyrians, the Babylonians, the Persians, and the Arabs.

Therefore, the use of the term Biblische Archäologie is extremely controversial (Rodrigues, 2017). There are, however, other aspects that add to this controversy. When Biblische Archäologie started to refer to archaeological excavations and retrieving of material culture from the ground, it was understood as an Altertumswissenschaft (Baentsch, 1909), that is, the study of real touchable things - of realia - in the form of artifacts and structures related to the Bible. Therefore, as the klassische Altertumswissenschaft departed from classic written documents to

3 Kalthoff, Handbuch der hebräischen Alterthümer (1840); Volz, Die biblischen Altertümer (1914); Rosenmüller, Handbuch der biblischen Alterthumskunde (1823); Allioli, Handbuch der biblischen Alterthumskunde 1 u. 2 (1844); Faber, Archäologie der Hebräer (1773); Wette, Lehrbuch der Hebräisch-Judischen Archäologie (1814); Benzinger, Hebräische Archäologie (1894). 
understand the material remains of the ancient Greeks and Romans, Biblische Archäologie used the Biblical text to conduct excavations and interpret its results. Consequently, Biblische Archäologie is intrinsically related to Biblical studies in Germany - or among German-speaking scholars.

When Dever advocates against the use of 'biblical archaeology', although he is not really proposing the laicization of the archaeological practice in Palestine ${ }^{4}$, he makes an important contribution towards the independence of the discipline. He stresses the importance to follow its own methodologies and theoretical discussions, inspired by the trend of New Archaeology. One important point in the way of thinking of Processual archaeology is the understanding of Material Culture as an evidence in itself, capable of giving information about the society in which it was created, independent of any written sources (Binford, Binford, 1968). Therefore, a Bible-oriented archaeology is intrinsically problematic, because it is oriented by a textual source.

New Archaeology developed in the United States, but soon became mainstream in theoretical discussions in several countries. In the 1980s, archaeology opens itself to Postmodernism, in the form of Postprocessualism. Postprocessual archaeology is considered the most deconstructionist of all archaeological schools of thought.

As a matter of fact, some cases in which archaeological evidence was previously understood as proof of biblical accounts, do not have the material support anymore. This is true, for example, for the narratives of the Patriarchs from the book of Genesis (12-50), the conquest of Canaan by the Israelites presented in Joshua (6-12), some of the descriptions of cultic practices of the Deuteronomy (Dever, Clarke, 1977; Finkelstein, 1988; Biran, 1994; Finkelstein, Silberman, 2002; Dever, 2003b; Bartlett, 2009).

On the other hand, there is still a strong appeal to traditional biblical archaelogy, that insists upon emphasizing the secondary role of archaeology in the reconstruction of the history of ancient Israel, prompted

\footnotetext{
4 Although Dever has been known for his campaign against the traditional biblical orientation of the archaeological practice in Israel and the importance to follow the mainstream global archaeology ((see Neil A. Silberman 1998, 177)), he does believe that archaeology should illuminate the Bible, or even prove it right (Dever 1982, 1995, 2001; see Finkelstein 2007.)
} 
and sometimes sponsored by religious interests. The insistent search for evidence of the glorious reign of David and Solomon as presented in the books of Samuel (1-2Sam) and Kings $(1 \mathrm{Kg})$ illustrates this perspective.

Besides an entire trajectory of conquests and building activities, there is no archaeological evidence to match with the biblical narrative of the United Monarchy. More recently, after a century and a half of fieldwork in Jerusalem, Eilat Mazar's excavations at sites such as the City of David and the Ophel produced pieces of evidence (so she recognizes) of the historical accuracy of the Bible. Among them are artifacts which she interpreted as belonging to the palace of the biblical King David (Mazar, 2006; 2009). Another example is the excavations of Yosef Garfinkel and Saar Ganor at the site of Khirbet Qeiyafa, between 2007 and 2013 - a project, which is well-known for the publicity they created after the excavators concluded that they were digging a Judahite stronghold from the time of the biblical King David (Garfinkel, Ganor, 2009; Garfinkel, Ganor, Hasel, 2014).

In both cases, the finds are supposed to attest the importance of Jerusalem and the well-organized administrative system during the $10^{\text {th }}$ century BCE, as described in the biblical text. The results of the excavations of both sites have been vehemently contradicted; they were considered ultimate examples of circular argumentation that uses the Bible as primary evidence of its own accuracy (Finkelstein et al., 2007; Finkelstein, 2011; Faust, 2012; Na'aman, 2008a, 2008b; Dagan, 2009; Finkelstein, Piasetzky, 2010; Finkelstein, Fantalkin, 2012).

Alternatively, to counteract this trend, there are situations in which the link with the biblical text is especially avoided. For example, in the context of the debate on the Chronology of the Iron Age strata in the Levant, Israel Finkelstein (1996; Finkelstein, Piasetzky, 2011) suggested to lower the dates of the Iron Age IIa, which is traditionally based on the biblical narrative of the United Monarchy, from the $10^{\text {th }}$ century BCE to the first half of the $10^{\text {th }}$ BCE until the late $9^{\text {th }}$ or even early $8^{\text {th }}$ centuries BCE.

For this reason, Finkelstein considers his work to be 'Archaeology of the Iron Age', with no prior connections to any biblical periodization. For him, if one forgets the biblical background and tries to understand sites such as Megiddo - and many other interpreted according to the same circular reasoning - by means of the archaeological record, the traditional dating would not stand the stratigraphy. This is what he proposed first with relative chronology, and later, suggesting absolute dating, with the 
development of the carbon 14 method (Finkelstein, Piasetzky, 2010). His starting point is the archaeological material interpreted according to archaeological parameters.

This is an example of the attempt to an archaeological practice per se, although in a site that might be important for biblical history. Historians are welcome to adopt the archaeological information to their effort in order to better understand ancient Israel, but how the records are going to be written is a matter of the researcher's agenda and compromise.

\section{Final Remarks}

Archaeology in the Near East has been practiced from the 19th century throughout the Wars and the Mandates by amateur travellers, army engineers, missionaries, priests and pastors - and sometimes by formed archaeologists; after that, work was carried out by national schools, then, again, by foreign institutions, until our days. The discipline was undoubtedly shaped by all the political events in the Near East, becoming sometimes more religious or national-oriented.

There is no need for a consensual approach or a unified terminology for the archaeological practice in the Near East. However, the lack of engagement among its current practitioners with this long history of the discipline puts them in a dangerous position of repeating and reproducing the same old discourses, unaware of the discipline's own power and implications.

Indeed, 'Biblical Archaeology' should be seen as a historical phenomenon, linked to specific mindsets of theological discussions and political interests from the time in which it developed (Silberman, 1982). Moreover, early research results should be re-examined in the light of the epistemological context they where first connected. Finally, future work should compromise in making its starting point and agendas very clear, in favor not only of a more transparent practice of archaeology, but one engaged not in reproducing traditional concepts anymore, which are usually dated and oppressive. 


\section{Acknowledgments}

Many years ago, Professor Pedro Paulo Funari taught me how to be critical, how not to take things for granted, how to always consider people's intentions and agendas. His intentions were to make a good student and researcher out of me, someone capable of thinking outside the lines of an academic text. The effects, however, were much broader than that: he changed my way of thinking not as a scholar, but as a person. For this - and for several other lessons -, I am extremelly grateful for having the opportunity of being pupil of such a great scholar and supporter of the search for knowledge. Ancient History and Archaeology are much richer thanks to your dedicated contribution and kindness. Thank you, Professor!

\section{References}

ALBRIGHT, William. F. The Archaeology of Palestine and the Bible. Fleming H. Revell Company, 1933.

ALBRIGHT, William. F. From the Stone Age to Christianity: Monotheism and the Historical Process. Baltimore: The John Hopkins Press, 1940.

ALBRIGHT, William. F. Archaeology, historical analogy $\mathcal{E}$ early Biblical tradition Louisiana State University Press, 1966.

ALBRIGHT, William. F. Archaeology and the religion of Israel. 5th edition. London: Westminster John Knox Press, 2006 [1946].

BALTER, Michael. Archaeology in the Holy Land. Science. Vol. 287, Nr. 5450, 2000, p. 28-29.

BARTLETT, John R. Archaeology: In. LIEU, J. M. and ROGERSON, J.W. (eds.) The Oxford Handbook of Biblical Studies. Oxford: OUP, 2009, p. 54-73.

BEN-YEHUDA, Nachman; KOHL, Philip; KOZELSKY, Mara. Selective Remembrances: Archaeology in the Construction, Commemoration and Consecration of National Pasts. Chicago: University of Chicago Press, 2007.

BINFORD, Sally. R.; BINFORD, Lewis. R. New Perspectives in Archaeology. Chicago: Aldine Publishing Company, 1968. 
BIRAN, Avraham. Tel Dan: Biblical Texts and Archaeological Data. In: COOGAN, et. al. (eds.) Scripture and Other Artifacts. Louisville: John Knox Press, 1994, p. 1-17.

BOHANNON, John. Palestinian Archaeology Braces for a Storm. Science. Vol. 312, Nr. 5772, 2006, p. 352-353.

BURKE, Aaron A. The Archaeology of the Levant in North America: The Transformation of Biblical and Syro-Palestinian Archaeology. LEVY, Thomas E. Historical Biblical Archaeology and the Future: The New Pragmatism. New York: Routledge, 2014, p. 81-95.

CLARKE, David L. Archaeology: The Loss of Innocence. Antiquity. Vol. 47, Nr. 185, 1973, p. 6-18.

CLINE, Eric, H. Biblical Archaeology: A Very Short Introduction. Oxford: OUP, 2009.

CROSS, Frank M. W. F. Albright's View of Biblical Archaeology and Its Methodology. BA. Vol. 36, Nr. 1, 1973, p. 2-5.

DAGAN, Y. Khirbet Qeiyafa in the Judean Shephelah: Some Considerations. Tel Aviv. Vol. 36, 2009, p. 68-81.

DAVIS, Thomas W. Shifting Sands: The Rise and Fall of Biblical Archaeology. Oxford: OUP, 2004.

DEVER, William G. Retrospects and Prospects in Biblical Archaeology. BAR Vol. 45, 1982, p. 102-112.

DEVER, William G. Will the Real Israel Please Stand up: Archaeology and Israelite Historiography. BASOR. Vol. 297, 1995, p. 61-80.

DEVER, William G. Biblical Archaeology. In MEYERS, E.M. (ed.), The Oxford Encyclopedia of Archaeology in the Near East.Oxford: OUP, 1997, p. 315-319.

DEVER, William G. Excavating the Hebrew Bible, or Burying It Again? BASOR. Vol. 322, 2001, p. 67-77.

DEVER, William G. What Did the Biblical Writers Know and When Did They Know It?: Grand Rapids: Eerdmans, 2001. 
DEVER, William G. Watchamacallit: Why It's so Hard to Name Our Field? BAR. Vol. 4, 2003, p. 56-61.

DEVER, William G. Who Were the Early Israelites, and Where Did They Come from? Grand Rapids: Eerdmans, 2003.

DEVER, William G., and CLARKE, M. The Patriarchal Traditions: Palestine in the Second Millennium BCE: the Archaeological Picture. In HAYES, J.H. and MILLER, J.M. (eds.) Israelite and Judaean History. London: S.C.M. Press, 1977, p. 70-120.

DÍAZ-ANDREU, Margarita. A World History pf Nineteenth-century arcaheology: Nationalism, colonialism and the past. Oxford: OUP, 2007.

FAUST, Avraham. Did Eilat Mazar Find David's Palace? BAR. Vol. 38, Nr. 5, 2012, p. 47-52.

FINKELSTEIN, Israel. The Archaeology of the Israelite Settlement. Jerusalem: Israel Exploration Society, 1988.

FINKELSTEIN, Israel.. The Archaeology of the United Monarchy: An Alternative View. Levant. Vol. 28, Nr. 1, 1996, p. 177-87.

FINKELSTEIN, Israel. Digging for the Truth: Archaeology and the Bible. In SCHMIDT, B. (ed.) The Quest for the Historical Israel. Atlanta: Society of Biblical Literature, 2007, p. 9-20.

FINKELSTEIN, Israel. The "Large Stone Structure" in Jerusalem: Reality Versus Yearning.ZDPV. Vol. 127, Nr. 1, 2011, p. 1-10.

FINKELSTEIN, Israel. The Iron Age Chronology Debate: Is the Gap Narrowing? NEA. Vol. 74, Nr. 1, 2011, p. 50-54.

FINKELSTEIN, Israel; FANTALKIN, Alexander Khirbet Qeiyafa: An Unsensational Archaeolgical and Historical Interpretation. Tel Aviv. Vol. 39, 2012, p. 38-63.

FINKELSTEIN, Israel et al. Has the Palace of King David in Jerusalem Been Found? Tel Aviv. Vol. 34, 2007, p. 142-164.

FINKELSTEIN, Israel; PIASETZKY, E. Khirbet Qeiyafa: Absolute Chronology. Tel Aviv. Vol. 37, 2010, p. 84-88. 
FINKELSTEIN, Israel; PIASETZKY, E. The Iron I/IIA transition in the Levant: A Reply to Mazar and Bronk Ramsey and a New Perspective. Radiocarbon. Vol. 52, Nr. 4, 2010, p. 1667-80.

FINKELSTEIN, Israel; SILBERMAN, Neil A. The Bible Unearthed: Archaeology's New Vision of Ancient Israel and the Origin of Its Sacred Texts. New York: Simon and Schuster, 2001.

FRANKEN, H.J.; FRANKEN-BATTERSHILL, C.A. A primer of Old Testament archaeology. Leiden: Brill, 1963.

FUNARI, Pedro Paulo A.; FERREIRA, Lucio M. A Social History of Brazilian Archaeology: a case study. BHA. Vol. 16, Nr. 2, 2008, p. 18-30.

GARFINKEL, Y.; GANOR, S. Khirbet Qeiyafa: The 2007-2008 Excavation seasons. Jerusalem: Israel Exploration Society, 2009.

GARFINKEL, Y.; GANOR, S.; HASEL, M. G. Khirbet Qeiyafa: Excavation Report 2009-2013: Stratigraphy and Architecture (Areas B, C, D, E) Jerusalem: Israel Exploration Society, 2014.

GNECCO, Cristobal. Caminos de la Arqueología: de la violencia epistémica a la relacionalidad. Boletim do Museu Paraense Emilio Goeldi. Vol. 4, Nr. 1, 2009, p. 15-26.

GONZÁLEZ-RUIBAL. Introduction. In Reclaiming Archaeology. New York: Routledge, 2013, p. 1-30.

HABER, Alejandro F. Un-disciplining Archaeology. Archaeologies. Vol. 8, Nr. 1, 2012, p. 55-66.

HABER, Alejandro F.; ROBERTS, Amy. Histories of the Archaeological Discipline> Issues to consider. In SMITH (ed.) Encyclopedia of Global Archaeology.New York> Springer, 2014, p. 3411-3415.

HAMILAKIS, Yannis. The Nation and its ruins: Antiquity, archaeology, and national imagination in Greece. Oxford: OUP, 2009.

HINGLEY, Richard. Roman officers and English gentlemen: The Imperial origins of Roman archaeology. London: Routledge, 2000.

HODDER, Ian. Reading the Past. Cembridge: CUP, 2003. 
HÜBNER, Ulrich. Biblische Archäologie Und Hebräische Lexikographie Im Hebräischen Handwörterbuch Von Gesenius. In $\mathrm{SCHORCH}$; WASCHKE (eds.) Biblische Exegese Und Hebräische Lexikographie. Berlin: de Gruyter, 2013.

KENYON, Kathleen. Archaeology in the Holy Land. New York: Praeger, 1960.

KOHL, Philip L.; FAWCETT, Clare P. Archaeology in the service of the State: theoretical considerations. Cambridge: CUP, 1995.

MAGNESS, Jodi. The Archaeology of the Holy Land: From the Destruction of Solomon's Temple to the Muslim Conquest. Cambridge: CUP, 2012.

MARCHAND, Suzanne, Down from Olympus: Archaeology and philhellenism in Germany, 1750-1970. Princeton: PUP, 1996.

MAZAR, Amihai. Archaeology of the Land of the Bible: 10,000-586 B.C.E. New York: Doubleday, 1990.

MAZAR, Eilat. The Palace of King David Excavations at the Summit of the City of David: Preliminary Report of Seasons 2005-2007: Shoham Academic Research and Publication, 2009.

MAZAR, Eilat. Did I Find King David's Palace? BAR. Vol. 32, Nr. 1, 2006, p. 16-27.

NA'AMAN, Nadav. In Search of the Ancient Name of Khirbet Qeiyafa. Journal of Hebrew Scriptures. Vol. 8, 2008, 21.

NA'AMAN, Nadav. Shaaraim: The Gateway to the Kingdom of Judah. Journal of Hebrew Scriptures. Vol. 8, 2008, 24.

NEGEV, Avraham. Archaeological encyclopedia of the Holy Land. New York: Continuum, 2001.

ORSER, Charles E. Encyclopedia of Historical Archaeology. New York: Routledge, 2002.

RAD, Gerhard von. History and the Patriarchs. Expository Times. Vol. 72, Nr. 7, 1961, p. 213-216. 
RAINEY, Anson F. Herodotus' Description of the East Mediterranean Coast. BASOR. Vol. 321, 2001, p. 57-63.

RAST, Walter E. Through the Ages in Palestinian Archaeology: An Introductory Handbook. Harrisburg: Trinity Press, 1992.

RENFREW, Colin; BAHN, Peter. Archaeology: Theories, Methods and Practice. London: Thames \& Hudson, 2008.

RODRIGUES, Gabriella. German Biblical Archaeology: Retrospective of a Neglected Legacy. Heidelberg: heiDOK, 2017 10.11588/heidok.00022796.

SHARON, Ilan. Biblical Archaeology. In PEARSALL, Deborah M. (ed.) Encyclopedia of Archaeology. New York: Academic Press, 2008; P: 920-24.

SILBERMAN, Neil A. Digging for God and Country: Exploration, Archeology, and the Secret Struggle for the Holy Land, 1799-1917. New York: Knopf, 1982.

SILBERMAN, Neil A. Between Past and Present: Archaeology, Ideology and Nationalism in the Middle East. New York: Henry Holt, 1989.

SILBERMAN, Neil A. Whose Game Is It Anyway? The Political and Social Transformations of American Biblical Archaeology. In MESKELL, Lynn (ed.) Archaeology Under Fire: Nationalism, Politics and Heritage in the Eastern Mediterranean and Middle East. London: Routledge, 1998, p. 175188.

SOGGIN, Alberto J. Ancient Biblical Traditions and Modern Archaeological Discoveries. BA. Vol. 23, 1960, p. 95-100.

SUSSER, Asher. Israel, Jordan, and Palestine: The Two-State Imperative. Waltham: Brandeis University Press, 2012.

WRIGHT, George. E. Biblical Archaeology Today. BA. Vol. 10, Nr. 1, 1947, p. 7-24.

WRIGHT, George. E.. The Present State of Biblical Archaeology. In WILLOUGHBY, H.R. (ed.) The Study of the Bible Today and Tomorrow. Chicago: Univ. of Chicago Press, 1947.

WRIGHT, Ernest, G. Modern Issues in Biblical Studies: History and the Patriarchs. Expository Times. Vol. 71, Nr. 10, 1960, p. 292-296. 